\title{
THE ROLE OF REMITTANCES AS MORE EFFICIENT TOOL OF DEVELOPMENT AID IN DEVELOPING COUNTRIES
}

\author{
Robert Stojanov, Wadim Strielkowski ${ }^{\star}$
}

\begin{abstract}
:
This paper examines the effectiveness of remittances and official development assistance (ODA) in developing countries. It compares the outcomes of aid poured into the economies of the Third World for decades without any visible effect and remittances transferred by emigrants to their countries of origin which proved to be quite effective. We find that remittances have a stronger net positive effect on the increase of GDP per capita in developing economies than development aid. In addition, remittances tend to be higher than ODA funds, they are absorbed by 80-90 per cent (in comparison with 50 per cent of aid budgets spent on administrative and other costs) and do not hinge on institutional quality. The paper advocates the importance of remittances over ODA and supports the wide usage of coherent development policies executed by the developed Western economies with an aim to enhance transparent and efficient remittance transfers as one of the best methods to promote development in less-developed countries (e.g. economies in Africa, Asia or Latin America).
\end{abstract}

Keywords: developing countries, official development aid, remittances, international migration.

JEL Classification: F22, F24, J61, O55, P45

\section{Introduction}

Migration of the population can be perceived as the "coping strategy" in the sense of the reaction to the loss of employment or reduction in yields or as a long-term "adaptation strategy", for example, caused by the significant environmental change or climate variability (e.g. change of precipitation, extreme drought, etc. $)^{1}$ or, for example, the loss of housing options (construction of dams, urbanization)2. Households or

* Robert Stojanov, Department of Adaptation Research Strategies, Global Change Research Centre, Academy of Sciences of the Czech Republic, Bělidla 986/4a, 60300 Brno, CZ; Department of Social Geography \& Regional Development, Faculty of Science, Charles University in Prague, Albertov 6, 12843 Prague, CZ (stojanov@centrum.cz); Wadim Strielkowski, Department of Adaptation Research Strategies, Global Change Research Centre, Academy of Sciences of the Czech Republic, Bělidla 986/4a, 60300 Brno, CZ.The authors would like to thank to two anonymous PEP reviewers and Professor Ronald Skeldon from the University of Sussex for their assistance with this paper: Their remarks, insights and thorough review were very much appreciated. Support from the Grants No. CZ.1.05/1.1.00/02.0073, No. CZ.1.07/2.4.00/31.0056, MSM 0021620831, and No. P404/10/0581 is gratefully acknowledged.

1 The environmental change and migration approach is described by Stojanov, Kavanová (2009), the concept climate change and migration as adaptation is characterised by Stojanov, Duži (2013).

2 About the concept and case study see Cahlíková, Stojanov (2013). 
community members often send their families to bigger cities or abroad in order to ensure additional sources of income or to increase their skills (or education). The links between migration and development are examined with a varying degree of intensity from the $2^{\text {nd }}$ half of the 1990 s, when we can speak about research in the sense of a new paradigmatic approach to the so-called "migration and development nexus“" (Stojanov, Strielkowski, Drbohlav, 2011). Therefore, for many people migration represents the path that allows them to escape from the economic and social poverty, or the way to their own personal development. ${ }^{3}$

Stojanov, Strielkowski and Drbohlav (2011) present some reasons for increasing interest about migration and development linkages during the last two decades. According to them it is caused by the rise in the absolute number of immigrants and the ageing population in developed countries. Another important reason is disillusionment with the failures of traditional development interventions, such as official development assistance (ODA) and the consequent search for alternative options, in which such issues as remittances received considerable attention and importance. Another reason may be the annually increasing amount of remittances, respectively the stability of this form of support compared to other external interventions and flows such as ODA or foreign direct investment (FDI).

It was a disappointing result and controversy surrounding the provision of total USD 2 trillion within the frame of development aid for last six decades that caused much controversy over its effectiveness and meaningfulness. ${ }^{4}$ In addition, a fact of unclear financial stability of the financial flows which is very often used as a political and economic tool by donor countries to developing countries must be added as an additional argument.

The main objective of this paper is to analyse the stability of the two major developments of financial flows taking into account the current global economic crisis. The authors try to answer the following research questions: What are the main approaches to evaluating the effectiveness of the provision of ODA flows and remittances in reducing poverty in developing countries? Which of these financial flows are more stable with respect to flows into developing economies? How important is the current economic crisis (recession) for the stability of these flows into the developing world? Do remittances have a larger net effect on economic growth expressed as the annual growth of GDP per capita in developing countries?

This paper offers a discussion based on an analysis of sources of empirical-research character, theoretical approaches to the topic selected development interventions and the empirical model based on panel data and 2SLS estimations.

3 The causes of migration are better explained by the migration theories (see for instance the classic paper Massey et al. 1993), which exceed the scope of this paper as well as the economic development theories (for details see Horky, 2011).

4 For more details see Stojanov and Jamborová (2008). 


\section{Development Aid Efficiency Discussion}

The usefulness of foreign aid has been characterised over the years by debates, with aid optimists at one extreme and aid sceptics at the other (see for example Burnside and Dollar, 2000; Collier and Dollar, 2002; Dalgaard, Hansen and Tarp, 2004; Loots, 2006 or most recently Moyo, 2009). The aid debate has been recently intensified as a result of net ODA flows fluctuation to low and middle income economies (see Table 1) and their stagnation or drop in real terms compared to 2009 (2010) prices and net ODA combined gross national income (GNI) (see Table 2).

Table 1

Net Official Development Assistance in Low Income and Middle Income Economies in 1989-2011 (current USD billion)

\begin{tabular}{|l|c|c|c|c|c|c|c|c|c|}
\hline & $\begin{array}{c}1989- \\
1990 \\
\text { average }\end{array}$ & $\begin{array}{c}1994- \\
1995 \\
\text { average }\end{array}$ & $\begin{array}{c}1999- \\
2000 \\
\text { average }\end{array}$ & $\mathbf{2 0 0 6}$ & $\mathbf{2 0 0 7}$ & $\mathbf{2 0 0 8}$ & $\mathbf{2 0 0 9}$ & $\mathbf{2 0 1 0}$ & $\mathbf{2 0 1 1}$ \\
\hline Total ODA & 55 & 59 & 54 & 105 & 104 & 122 & 120 & 128 & 134 \\
\hline $\begin{array}{l}- \text { Low } \\
\text { income } \\
\text { economies }\end{array}$ & 34 & 34 & 28 & 48 & 45 & 50 & $\mathbf{5 6}$ & $\mathbf{5 9}$ & $\begin{array}{c}\text { no } \\
\text { verified } \\
\text { data }\end{array}$ \\
\hline $\begin{array}{l}\text { - Middle } \\
\text { income } \\
\text { economies }\end{array}$ & 43 & 17 & 47 & 35 & $\mathbf{3 6}$ & $\mathbf{4 1}$ & $\mathbf{3 4}$ & $\mathbf{3 3}$ & $\begin{array}{c}\text { no } \\
\text { verified } \\
\text { data }\end{array}$ \\
\hline $\begin{array}{l}\text { Low and } \\
\text { Middle } \\
\text { income } \\
\text { economies }\end{array}$ & 77 & 41 & 75 & 83 & 81 & 91 & 90 & 92 & $\begin{array}{c}\text { no } \\
\text { verified } \\
\text { data }\end{array}$ \\
\hline
\end{tabular}

Source: data from $\operatorname{OECD}(2011,2012)$ and own calculations.

Table 2

Total Official Development Assistance at 2009 Prices and ODA/GNI Index in 1989-2011 (current USD billion)

\begin{tabular}{|c|c|c|c|c|c|c|c|c|c|}
\hline & $\begin{array}{c}1989-1990 \\
\text { average }\end{array}$ & $\begin{array}{c}1994-1995 \\
\text { average }\end{array}$ & $\begin{array}{c}1999-2000 \\
\text { average }\end{array}$ & 2006 & 2007 & 2008 & 2009 & 2010 & 2011 \\
\hline Total ODA & 55 & 59 & 54 & 105 & 104 & 122 & 127 & 128 & 134 \\
\hline $\begin{array}{l}\text { Total ODA at } \\
2009 \text { prices }\end{array}$ & 80 & 77 & 76 & 105 & 104 & 122 & 120 & 128 & ${ }^{*} 125$ \\
\hline ODA/GNI** & 0.27 & 0.27 & 0.22 & 0.30 & 0.27 & 0.30 & 0.31 & 0.32 & 0.31 \\
\hline
\end{tabular}

${ }^{*}$ At 2010 prices taking account of both inflation and exchange rate movements.

** UN recommended target is 0.7 .

Source: data from $\operatorname{OECD}(1999,2011,2012)$ and own calculations.

5 The contrast between total flows of ODA to low-income and middle-income economies and total ODA is caused by overhead costs of national agencies/governments and by funds taking into account such as possible ODA costs, however they are spent within donor country (e.g. service for asylum seekers, development education support, etc.). See note 9. 
Some "aid pessimists" argue that aid only works in place with "good" policies (Burnside and Dollar, 2000; Collier and Dollar, 2002). Loots (2006) points out that the aid is missing its target in filling the investment-savings gap, which leads to the increase in investment and higher and more sustainable growth with a subsequent increase in per capita income.

Easterly (1999) brings the example of Zambia, which could have long boasted incomes surpassing USD 20,000 per capita, but due to the inefficiencies in distributing foreign aid, still yields a per capita income under USD 500. Loots (2006) supports this finding with the fact that the African funding need has not been fulfilled despite the fact that Western countries have spent UDS 450 billion on foreign aid to Africa over the past 40 years.

Ovaska (2003) is even more critical in his study where he examined the effect of development aid on economic growth for 1975-1998 on the basis of sample of 86 Least Developed Countries (LDCs). He used two alternative data sets for aid, compared them with previous studies of aid effectiveness and used a more advanced measure of the quality of governance. The results indicate a negative relationship between development aid and economic growth. He found that a 1.0 percent increase in aid as a percentage share of GDP decreased annual real GDP per capita growth by 3.65 percent.

"Aid optimists" emphasizes the importance of growing development aid for developing countries. In the context of sub-Saharan Africa they are convinced this region is simply too poor to grow without foreign assistance and especially the continent needs a big push in the form of aid flows to end poverty (Sachs, 2005). Further, the optimists argue that development aid has a positive and statistically significant causal effect on growth over the long run (Arndt, Jones, Tarp, 2010), and Gyimah-Brempong, Racine, and Gyapong (2012) find that aid has a significant and positive impact on physical capital investment. In this way Gupta, Pattillo and Wagh (2006) claim that harmonization of donor practices and alignment of aid flows with the priorities of recipient countries can enhance aid effectiveness.

The main purpose of ODA provision was to fight poverty in the Third World. However, the effectiveness of ODA for the last five decades, particularly in LDCs, is unsatisfactory. For example, the success in poverty alleviation at the global level as the most important goal of development interventions is, above all, based on the rapid long-term economic growth in China and India in the last few decades, as well as the implementation of other quantitative targets within the framework of the Millennium Development Goals. The global measures are not very useful in this context simply because of the significance of China and India in these figures (see Collier, 2007). It might be that several developed countries are beginning to re-think their emphasis on poverty alleviation as a primary development strategy.

Debates about ODA reveal its risk factors which can hinder development in poor countries. One of the frequently mentioned factors is the limited efficiency and certain negative effects of ODA provision (Bauer and Yamey 1985; Jamborová, 2008). Lancaster (1999) claims that the results of ODA-financed projects in Africa were the least effective in achieving their goals and sustaining the achievements among other similar projects in the world. 
Moreover, critical voices rise over the present state of development programme implementation. The critics state that these programme comes with many errors and the development interventions need urgent changes towards restructuring ODA and substituting it with other tools of development and growth, such as remittances (Chambers, 2003; Macrae, 2001). It is often claimed that ODA is used as a tool for increasing the aid dependency of developing countries (Lensink and White, 2001; Lancaster, 1999). Furthermore, there are some negative aspects of ODA provision and in this context Macrae (2001) calls for an attention to the fact that the ODA still remains an instrument of foreign policy. Similarly, Thérien and Lloyd (2000) argue that development aid provides the North the control over the South as a part of a (neo-colonial) development concept, based on agro-mineral specialisation as a whole (Amin, 2006). Thérien and Lloyd (2000) claim that ODA, that represented financial infusions close to USD 1 trillion $^{6}$ for the half century since the late 1940s (World Bank, 1998), dominated the North-South economic relations.

\section{Remittance Transfers and Development}

The total value of remittances has been increasing steadily over the past decade and the World Bank estimates that remittances totalled USD 440 billion in 2010, of which USD 325 billion went to developing countries (World Bank, 2012).

Low income economies allocate approximately half of remittances per capita in USD 30.4 for 2011 compared with middle income economies. Nevertheless, the importance of the remittances for these countries from macro-economic perspective is more significant. The remittances form about 7.25 percent of GDP of low income economies in 2010, compared to 1.55 percent of GDP of middle income countries (see Table 3 ). Dependency on remittances of low income countries dramatically increased from 2 percent of GDP in 1992-1997 (Stojanov, Strielkowski and Drbohlav, 2011).

Table 3

Remittances Flows and Population in Low and Middle Income Economies in 2011

\begin{tabular}{|l|c|c|c|}
\hline & $\begin{array}{c}\text { Remittances } \\
\text { (current USD billions) }\end{array}$ & $\begin{array}{c}\text { Remittances } \\
\text { per capita (in USD) }\end{array}$ & $\begin{array}{c}\text { Remittances as a share } \\
\text { of GDP (percentage) }\end{array}$ \\
\hline Developing countries & 351 & 61.6 & 1.64 \\
\hline $\begin{array}{l}\text { - Low income } \\
\text { economies }\end{array}$ & 28 & 30.4 & 7.25 \\
\hline $\begin{array}{l}\text { - Middle income } \\
\text { economies }\end{array}$ & 324 & 68.9 & 1.55 \\
\hline World & 483 & 69.0 & 0.74 \\
\hline
\end{tabular}

* for 2010

Source: Stojanov, Strielkowski and Drbohlav (2011)

6 Currently more than USD 2 trillion. 
In the context we would like to point out to the fact that remittances flows to low-income economies retained their growth despite economic crisis impacts (for details see Table 4).

Remittances indisputably represent an important channel of levelling unemployment and increasing welfare. There are a number of studies that are dealing with the effects of remittances on development. Some remittances studies find that remittances are generally spent on consumer goods (such as food and clothing or housing). For instance, Durand et al. (1996) report that 10 percent of their sample of Mexican migrants to the United States who reported that they sent remittances or brought savings back with them spent at least some of the remitted money (the so-called "migradollars") productively. In addition to that, 14 percent reported that they spent some of their migradollars on housing and the remaining 76 percent reported that they spent the "migradollars" only on consumption.

Remittances contribute to an increase of recipient prosperity and have development impact on local scale together with related multiply effects, also in cases when they are aimed "only" to consumption. In this way Stahl and Arnold (1986) show example of Asia, where remittances are spent on home made goods and services, and are able to provide important stimulus to local industries and economics in migration resource countries. Moreover, remittances (although constitute small part of the whole amount) are used for investment on building infrastructure, schools, houses etc., contribute to improvement or modernization of local economic activities or give rise to small enterprises. These serve as a key impulse to start or keep development on local or regional scale (Stojanov, Strielkowski, Drbohlav, 2011).

With regard to this, Skeldon (2002) argues using the example of the expenditure on private house construction that can stimulate local building enterprise helping to generate employment and trade in materials. The key point is that the so-called consumption expenditure has investment externalities and a clear and hard distinction between the two categories is deceptive.

However, there is another use of remittances. According to Adams (1998) even though a small proportion of remittances may be invested directly by migrants or their families, remittances can be channelled into productive use by the banking system. For instance, Mesnard (1999) found that the majority of entrepreneurial projects started by returned migrants were financed by their own savings.

Further, Adams and Page (2005) base their studies on macro-data comparison demonstrating that international migration and remittances significantly reduce the level, depth, and severity of poverty in low-income and middle-income developing countries. A similar increase in per capita official international remittances will lead, on average, to a 3.5 percent decline in the share of people living in poverty.

At the same time Görlich and Trebesch (2008) pay attention to social aspects of migration (on example of mass seasonal Moldavian emigration), however, they agree that migration is generally confirmed as an important coping strategy for the poor and may thus contribute to considerably improved standards of living in impoverished areas. 
Joly (2005) draws attention to dependence on remittances. Taylor (1992) shows the ambiguity of remittance impact on the increase of income from research provided among Mexican farmers in 1982. Remittances tend to decrease the longer the migrant community stays in the destination country. When an economy is too dependent on remittances a decrease of this money can have severe negative effects on the national income (De Bruyn and Wets, 2006).

\section{ODA and Remittances Transfers: A Comparative Analysis}

Further, the development potential of external financial flows (such as remittances, ODA, FDI) generally depends on their stable flow. There are many reasons why experts are now interested in remittances as a development tool in more detail. Among six of the most important reasons there are:

1. Decrease in the amount of ODA as a share of Gross National Income (GNI) ${ }^{7}$ for the last two decades (see Table 2), and

2. stagnation or decrease of ODA in absolute terms (see Table 1),

3. dubious efficiency of ODA provision for the past half century,

4. increase in the amount of remittances transmitted to recipient countries for the past half century in contrast with ODA (see Table 3 ) with the presumption of more effective uses than ODA,

5. in contrast to remittances not all financial sources within the ODA framework are intended for development purposes, because within the funds there are calculated debts relief, refugee and asylum seekers assistance, administrative costs, etc., ${ }^{8}$ and

6. greater stability of remittances, as compared with other foreign financial flows, such as Foreign Direct Investment (FDI) or ODA.

Some statistics show that a greater amount of formal remittances is transferred to developing regions than the amount provided by ODA. In 2011, all developing countries received about USD 351 billion in the form of formal remittances. This comes in contrast with about USD 134 billion received in the form of ODA from OECD countries (see Table 5). Nevertheless, we must take into account that there are significant administrative and other expenses included within the framework of ODA which have not a positive development impact on poor people.

7 GNI is the sum of all income earned while producing goods and services within a nation's borders. It differs from gross domestic product (GDP), which gauges economic activity on expenditure (more at http://www.investopedia.com/terms/g/gdi.asp\#ixzz2580BGPkz).

8 The costs can reach about 50 percent of bilateral development aid budget. For more details see Stojanov and Jamborová (2008). 
Table 4

Distribution of Formal Remittances and ODA in 1971-2011 (in current USD billions)

\begin{tabular}{|l|c|c|c|c|c|c|c|c|c|c|}
\hline \multirow{2}{*}{ Regions / year } & \multicolumn{2}{|c|}{$\begin{array}{c}1971-1980 \\
\text { average }\end{array}$} & \multicolumn{2}{|c|}{$\begin{array}{c}1981-1990 \\
\text { average }\end{array}$} & \multicolumn{1}{c|}{$\begin{array}{c}1991-2000 \\
\text { average }\end{array}$} & \multicolumn{2}{c|}{$\begin{array}{c}2001-2010 \\
\text { average }\end{array}$} & \multicolumn{2}{|c|}{2011} \\
\cline { 2 - 11 } & ODA & Remit. & ODA & Remit. & ODA & Remit. & ODA & Remit. & ODA & Remit \\
\hline $\begin{array}{l}\text { Developing } \\
\text { countries }\end{array}$ & 17 & 5.8 & 36 & 22 & 54 & 55 & 97 & 213 & 134 & 351 \\
\hline $\begin{array}{l}\text { - Low income } \\
\text { economies }\end{array}$ & 3.4 & $\mathbf{0 . 3}$ & 9.3 & $\mathbf{1 . 2}$ & 13 & $\mathbf{2 . 4}$ & 26 & $\mathbf{1 3}$ & $*$ & $\mathbf{2 8}$ \\
\hline $\begin{array}{l}\text { - Middle income } \\
\text { economies }\end{array}$ & 11 & $\mathbf{5 . 6}$ & 20 & $\mathbf{2 1}$ & 31 & $\mathbf{5 3}$ & 47 & $\mathbf{2 0 0}$ & $*$ & $\mathbf{3 2 4}$ \\
\hline
\end{tabular}

${ }^{*}$ no verified data

Source: data from World Bank (2012), OECD (2012), Mohapatra, Ratha and Silwal (2011).

Table 5

Distribution of Formal Remittances and ODA in 2007-2011 (in current USD billions)

\begin{tabular}{|l|c|c|c|c|c|c|c|c|c|c|}
\hline \multirow{2}{*}{ Regions / year } & \multicolumn{2}{|c|}{2007} & \multicolumn{2}{c|}{2008} & \multicolumn{2}{c|}{2009} & \multicolumn{2}{c|}{2010} & \multicolumn{2}{c|}{2011} \\
\cline { 2 - 12 } & ODA & Remit. & ODA & Remit. & ODA & Remit. & ODA & Remit. & ODA & Remit \\
\hline $\begin{array}{l}\text { Developing } \\
\text { countries }\end{array}$ & 104 & $\mathbf{2 7 8}$ & 122 & $\mathbf{3 2 5}$ & 120 & $\mathbf{3 0 7}$ & 128 & $\mathbf{3 2 1}$ & 134 & 351 \\
\hline $\begin{array}{l}\text { - Low income } \\
\text { economies }\end{array}$ & $\mathbf{4 5}$ & 16 & $\mathbf{5 0}$ & 22 & $\mathbf{5 6}$ & 22 & $\mathbf{5 9}$ & $\mathbf{2 5}$ & $*$ & 28 \\
\hline $\begin{array}{l}\text { - Middle income } \\
\text { economies }\end{array}$ & $\mathbf{3 6}$ & 261 & $\mathbf{4 1}$ & 303 & $\mathbf{3 4}$ & 285 & $\mathbf{3 3}$ & $\mathbf{2 9 6}$ & $*$ & 324 \\
\hline
\end{tabular}

* no verified data

Source: data from Mohapatra, Ratha and Silwal (2011), OECD (2011, 2012), World Bank (2012) and own calculations.

Tables 4 and 5 show that remittance transfers represent a more stable source of money than ODA. Unlike the development aid, remittances are not linked to the short-term interests of politicians. Furthermore, according to Wucker (2004) remittances might contribute to the soothing the negative shocks caused by the economic crises (migrants remit to support their families regardless of the crises).

Thence, remittance transfers tend to have higher development potential during the crisis because they can act quicker, be steadier and more efficient for the benefit of the locals than the other development tools. We are more likely to observe this when the regional economic crises strike (for example, in the case of the 1997-1998 economic crisis in South-East Asia). Migrants from the region increased their remittances when their home country was in distress and development aid dropped.

Tables 6, 7 and 8 shows the patterns of remittances and development aid that are transferred to South-East Asia, the region that was among the most affected ones during the regional economic crisis at the end of the 1990s. Available statistics show a slight short-term decline of remittance transfers in 1997-1998 (the time of the crisis outbreak) and their consequent increase during following years (1999-2000). For instance, 
Thailand experienced its remittance peak in 1996, which was repeatedly acquired in 2008 (for details see World Bank, 2012). However, this situation did not refer to the financial crisis. Instead, it was intended to demonstrate that remittances helped to overcome the worst short-term economic troubles in Malaysia, Indonesia and the Philippines.

Table 6

ODA and Formal Remittances in Selected South-East Asian Countries in 1981-1996 (in current millions USD)

\begin{tabular}{|l|c|c|c|c|c|c|c|c|}
\hline \multirow{2}{*}{ State / Year } & \multicolumn{2}{|c|}{$\mathbf{1 9 8 1 - 1 9 8 5}$ average } & \multicolumn{1}{|c|}{$\mathbf{1 9 8 6 - 1 9 9 0}$ average } & $\mathbf{1 9 9 1 - 1 9 9 5}$ average & \multicolumn{2}{c|}{1996} \\
\cline { 2 - 9 } & ODA & Remit. & ODA & Remit. & ODA & Remit. & ODA & Remit. \\
\hline Indonesia & $\mathbf{7 7 8}$ & ${ }^{*} \mathbf{8}$ & 1.427 & $\mathbf{1 1 8}$ & 1.715 & $\mathbf{3 6 1}$ & 1.071 & $\mathbf{7 9 6}$ \\
\hline Malaysia & 202 & no data & 253 & ${ }^{* * 118}$ & 152 & $\mathbf{1 3 9}$ & -457 & $\mathbf{1 6 4}$ \\
\hline Philippines & 394 & $\mathbf{8 9 9}$ & 912 & $\mathbf{1 . 1 9 4}$ & 1.239 & $\mathbf{3 . 1 5 7}$ & 898 & $\mathbf{4 . 8 7 5}$ \\
\hline Thailand & 427 & $\mathbf{7 4 2}$ & 589 & $\mathbf{8 9 6}$ & 689 & $\mathbf{1 . 1 1 0}$ & 828 & $\mathbf{1 . 8 0 6}$ \\
\hline
\end{tabular}

* data for 1983-1985, ** data for 1987-1990

Source: Data by World Bank (2012) and own calculations.

Table 7

ODA and Formal Remittances in Selected South-East Asian Countries in 1996-2000 (in current millions USD)

\begin{tabular}{|l|c|c|c|c|c|c|c|c|c|c|}
\hline \multirow{2}{*}{ State / Year } & \multicolumn{2}{|c|}{1996} & \multicolumn{2}{c|}{1997} & \multicolumn{2}{c|}{1998} & \multicolumn{2}{c|}{1999} & \multicolumn{2}{c|}{2000} \\
\cline { 2 - 12 } & ODA & Remit. & ODA & Remit. & ODA & Remit. & ODA & Remit. & ODA & Remit. \\
\hline Indonesia & 1.071 & $\mathbf{7 9 6}$ & 806 & $\mathbf{7 2 5}$ & 1.254 & $\mathbf{9 5 8}$ & 2.123 & $\mathbf{1 . 1 0 9}$ & 1.653 & $\mathbf{1 . 1 9 0}$ \\
\hline Malaysia & -457 & $\mathbf{1 6 4}$ & -241 & $\mathbf{1 9 4}$ & 202 & $\mathbf{1 9 0}$ & 147 & $\mathbf{3 2 2}$ & 46 & $\mathbf{3 4 2}$ \\
\hline Philippines & 898 & $\mathbf{4 . 8 7 5}$ & 680 & $\mathbf{6 . 7 9 9}$ & 614 & $\mathbf{5 . 1 3 0}$ & 686 & $\mathbf{6 . 7 1 7}$ & 572 & $\mathbf{6 . 9 6 1}$ \\
\hline Thailand & 828 & $\mathbf{1 . 8 0 6}$ & 623 & $\mathbf{1 . 6 5 8}$ & 698 & $\mathbf{1 . 4 2 4}$ & 1.013 & $\mathbf{1 . 4 6 0}$ & 696 & $\mathbf{1 . 6 9 7}$ \\
\hline
\end{tabular}

Source: Data by World Bank (2012).

Table 8

ODA and Formal Remittances in Selected South-East Asian Countries in 2000-2010 (in current millions USD)

\begin{tabular}{|l|c|c|c|c|c|c|}
\hline \multirow{2}{*}{ State / Year } & \multicolumn{2}{|c|}{2000} & \multicolumn{2}{c|}{ 2001-2005 average } & \multicolumn{2}{c|}{ 2006-2010 average } \\
\cline { 2 - 7 } & ODA & Remit. & ODA & Remit. & ODA & Remit. \\
\hline Indonesia & 1.653 & $\mathbf{1 . 1 9 0}$ & 1.441 & $\mathbf{2 . 2 1 6}$ & 1.178 & $\mathbf{6 . 4 8 0}$ \\
\hline Malaysia & 46 & $\mathbf{3 4 2}$ & 111 & $\mathbf{6 5 8}$ & 148 & $\mathbf{1 . 3 3 6}$ \\
\hline Philippines & 572 & $\mathbf{6 . 9 6 1}$ & 599 & $\mathbf{1 0 . 7 5 7}$ & 413 & $\mathbf{1 8 . 2 7 7}$ \\
\hline Thailand & 696 & $\mathbf{1 . 6 9 7}$ & -98 & $\mathbf{1 . 4 1 0}$ & -247 & $\mathbf{1 . 6 5 3}$ \\
\hline
\end{tabular}

Source: Data by World Bank (2012) and own calculations.

With the continually decreasing or stagnation of ODA (e.g. in the Phillipines), the aid was eventually seesawing (as in the case of the Malaysia and Thailand). This assistance 
variability did not meet the main objective of the development aid in times of crisis that hit the poorest strata of the society. In spite of that, we can confirm similar trend that remittances became a more stable source of income in the case of the recent global economic depression (see Tables 4 and 5).

Although the debate is still ongoing, we think that there might be reasons to believe in a counter-cyclical effect of remittance flows. Although international donors often tend to forget their promises even in the times of prosperity and abundance, development aid budgets might fall the victims of belt-tightening measures in times of economic turmoil. Instead, the motives for the remittance transfers might be strong enough not to depend on the current economic situation.

Brown (2006) stresses the importance of remittances in the context of Millennium Development Goals (MDG). In particular, poverty alleviation might be the one in the focus. According to Brown (2006), traditional tools such as ODA might not be sufficient instruments for MDG achievement. Eurostat's report (see Schoorl et al., 2000) explicitly stated that "[international] migration may be considered a tool for development, through remittances, and through investment of human capital by returning migrants".

Migrants' remittances have another advantage - the lion's share of remittances can be used directly by the households, communities and on regional development without any secondary costs. In addition, remittances provide more opportunities for being used by the poor recipients on the basis of their free will (e.g. consumption, investments, education, health care, houses building, reconstruction, etc.).

\section{Remittances, ODA on Economic Growth: An Empirical Model}

It is believed that remittances have been boosted thanks to both the structural increase of South-North and East-West migration over the past twenty years or so, as well as due to the rapid decrease in the price of financial products (opening and maintaining a bank account, using traveller's cheques, using cheap and sufficient money transfer agencies to send money abroad) and technological progress allowing the use of safer channels for transferring money (Internet and telephone banking). Recent experience of some EU countries (Germany or Austria) with Turkish workers in the 1960s and 1970s represents a good example of how these trends evolved (Glazar and Strielkowski, 2010).

\subsection{The empirical model}

It becomes quite clear that remittances might represent a more important driver of economic growth and development than ODA. In order to test this hypothesis, we apply the empirical approach. The empirical approach envisaged to unveil the relationship between remittances and economic growth that is presented below employs the model presented in (1). The model is an extension of the models used by Jha, Sugiyarto and Vargas-Silva (2009) and Vargas-Silva (2011) and is based on the two-stage least squares (2SLS) technique. The 2SLS technique is used to calculate the instrumental variables 
(IV) estimates in two stages: in the first stage each endogenous covariate is regressed on all exogenous variables in the model and the predicted values of the regressors are obtained. In the second stage, the regression model is estimated with endogenous covariate replaced with the predicted values from its first stage model.

The choice of SLS technique was not an accidental one. In order to decide whether to use OLS or 2SLS, we had to run statistical tests and decide upon the following trade-off: OLS has a smaller variance but 2SLS is consistent under more general conditions (see for example Cumby et al., 1983). The Hausman test is a widely-used general specification testing method for this and other situations where this trade-off is presents and it helped us to decide whether or not the difference between the two estimators was statistically significant (Hausman, 1978). In cases where the difference is significant, (an evidence that the more restricted, or "efficient", one is not consistent is present). Hausman tests were run for OLS and 2SLS versions of the model. In order to run Hausman test for 2SLS, the sigma more option was included to make the output correct. The obtained p-values were 0.0124 for model (1), 0.021 for model (2), 0.0118 for model (3), 0.0124 for model (4), 0.0124 for model (5), and 0.0124 for model (6). Since all p-values were below the .05 threshold, we were able to reject the null hypothesis at the $5 \%$ significance level. Thus, the use of 2SLS was justified and supported by the evidence that use of OLS was not consistent in our case.

Our resulting empirical model can be written as follows:

$$
\mathrm{g}_{\mathrm{it}}=\mathrm{f}\left(\mathrm{R}_{\mathrm{it}}, \mathrm{A}_{\mathrm{it}}, \mathrm{Y}_{\mathrm{it}}, \mathrm{S}_{\mathrm{it}}, \mathrm{O}_{\mathrm{it}}, \pi_{\mathrm{it}}\right)
$$

where $\mathrm{g}_{\text {it }}$ is the economic growth (the logarithm of the growth rate of GDP per capita) and $\mathrm{R}_{\mathrm{i}}$, is the natural logarithm of remittances as a percentage to GDP. $A_{i t}$, is the natural logarithm of the net ODA received (in current USD), $\mathrm{Y}_{\mathrm{it}}$ is the natural logarithm of GDP per capita (in current USD). $\mathrm{S}_{\mathrm{it}}$, is savings and $\mathrm{O}_{\mathrm{it}}$ is the natural logarithm of exports plus imports as a percentage of GDP and represents the openness of the economy. $\pi_{\mathrm{it}}$, is the annual percentage change in the GDP deflator (inflation rate).

\subsection{The data}

Our analysis employs panel data which implies that ODA and remittances are likely to be endogenous and should be treated as such.

The data was obtained from the "World Development Indicators \& Global Development Finance" database kept by the World Bank (World Bank, 2011) that is available online. The data include yearly observations from 1970 until 2009 of the following variables: the growth rate of GDP per capita expressed in \%, remittances as a percentage to GDP expressed in \%, net ODA received (in current USD), GDP per capita (in current USD), savings (in current USD), exports as a percentage of GDP expressed in \%, imports as a percentage of GDP expressed in \% and annual percentage change in the GDP deflator (inflation rate) expressed in $\%$. 


\subsection{Results and discussion}

Our results of 2SLS estimation based on the model presented in (1) are shown in Table 9. We run linear regression models with endogenous regressors using the stata ivreg command in Stata and employing different measures of ODA.

At first, we run our model with the total ODA. Then, we re-run the model using the annual data values of the ODA reported by United Nations (UN) agencies: UNHCR, UNICEF, UNRWA, UNTA, and WFP. The 2SLS standard errors reported in Table 9 are higher than in a standard OLS estimation which is an indication of the theoretical result that the variance of the 2SLS estimator is higher than the variance of the OLS estimator and is found in the similar studies (Cumby et al., 1983).

Our estimations show that in all 6 cases remittances tended to be more significant (positive and statistically significant) for growth measured by the annual growth of the world's GDP. However, when it comes to ODA, it appeared to be significant and positive only in the case of the development aid provided by UNTA (in all other cases the values were positive but insignificant).

Table 9

Results of the 2SLS Model Estimations: Annual GDP Growth in World (1970-2009)

\begin{tabular}{|c|c|c|c|c|c|c|}
\hline Variables & $\begin{array}{c}(1) \\
\text { Total ODA }\end{array}$ & $\begin{array}{c}(2) \\
\text { UNHCR }\end{array}$ & $\begin{array}{c}\text { (3) } \\
\text { UNICEF }\end{array}$ & $\begin{array}{c}\text { (4) } \\
\text { UNRWA }\end{array}$ & $\begin{array}{c}(5) \\
\text { UNTA }\end{array}$ & $\begin{array}{c}(6) \\
\text { WFP }\end{array}$ \\
\hline Remittances & $\begin{array}{l}3.411^{*} \\
(2.812)\end{array}$ & $\begin{array}{c}3.49 \\
(2.909)\end{array}$ & $\begin{array}{l}3.667^{*} \\
(2.923)\end{array}$ & $\begin{array}{c}3.659 \\
(2.879) \\
\end{array}$ & $\begin{array}{l}5.047^{\star *} \\
(2.628)\end{array}$ & $\begin{array}{c}3.559 \\
(2.787) \\
\end{array}$ \\
\hline ODA & $\begin{array}{c}0.066 \\
(1.877)\end{array}$ & $\begin{array}{l}0.026 \\
(.686)\end{array}$ & $\begin{array}{c}0.405 \\
(1.648)\end{array}$ & $\begin{array}{c}0.372 \\
(1.229)\end{array}$ & $\begin{array}{c}0.996^{* *} \\
(.437)\end{array}$ & $\begin{array}{l}0.264 \\
(.451)\end{array}$ \\
\hline GDP per capita & $\begin{array}{l}-1.083 \\
(2.822)\end{array}$ & $\begin{array}{l}2.309^{*} \\
(1.590)\end{array}$ & $\begin{array}{l}-2.512 \\
(4.148)\end{array}$ & $\begin{array}{l}-1.695 \\
(1.792)\end{array}$ & $\begin{array}{c}-1.913 \\
(1.591)\end{array}$ & $\begin{array}{c}-2.22 \\
(2.136)\end{array}$ \\
\hline Savings & $\begin{array}{l}9.160^{* *} \\
(4.112)\end{array}$ & $\begin{array}{c}9.315 \\
(6.202)\end{array}$ & $\begin{array}{l}9.573^{* *} \\
(4.336)\end{array}$ & $\begin{array}{l}9.656^{\star \star} \\
(4.296)\end{array}$ & $\begin{array}{c}10.53^{\star \star *} \\
(3.590)\end{array}$ & $\begin{array}{l}9.996^{\star *} \\
(4.176)\end{array}$ \\
\hline Openness & $\begin{array}{c}1.978 \\
(2.882) \\
\end{array}$ & $\begin{array}{c}1.735 \\
(2.926)\end{array}$ & $\begin{array}{c}1.118 \\
(3.834)\end{array}$ & $\begin{array}{c}1.659 \\
(2.935)\end{array}$ & $\begin{array}{c}0.056 \\
(2.789)\end{array}$ & $\begin{array}{c}0.746 \\
(3.235)\end{array}$ \\
\hline Inflation & $\begin{array}{c}-0.307^{\star \star *} \\
(.087)\end{array}$ & $\begin{array}{c}-0.305^{\star \star} \\
(.125)\end{array}$ & $\begin{array}{c}-0.314^{\star * *} \\
(.093)\end{array}$ & $\begin{array}{c}-0.306^{\star \star *} \\
(.077)\end{array}$ & $\begin{array}{c}-0.204^{\star *} \\
(.083)\end{array}$ & $\begin{array}{c}-0.323^{\star * \star} \\
(.086)\end{array}$ \\
\hline Constant & $\begin{array}{c}82.205 \\
(59.542)\end{array}$ & $\begin{array}{c}78.18 \\
(48.989)\end{array}$ & $\begin{array}{l}66.038^{*} \\
(68.462)\end{array}$ & $\begin{array}{c}71.760 \\
(54.181)\end{array}$ & $\begin{array}{c}46.706 \\
(47.825)\end{array}$ & $\begin{array}{c}55.808 \\
(58.844)\end{array}$ \\
\hline R-squared & 0.48 & 0.47 & 0.48 & 0.47 & 0.58 & 0.51 \\
\hline $\begin{array}{l}\text { Adjusted } \\
\text { R-squared }\end{array}$ & 0.33 & 0.32 & 0.33 & 0.32 & 0.45 & 0.42 \\
\hline $\begin{array}{l}\text { No of } \\
\text { observations } \\
\text { (years) }\end{array}$ & \multicolumn{6}{|c|}{ ונד } \\
\hline
\end{tabular}

Note: * Significant at the $10 \%$ level; ${ }^{* *}$ Significant at the $5 \%$ level; *** Significant at the $1 \%$ level; Standard errors are shown in parentheses.

Source: Authors own calculations. 
Figure 1 plots workers' remittances and remunerations as a percent of the GDP in 1982-2009. It is apparent that most of the global remittances go to middle-income countries. In addition, it is visible that low-income and lower middle-income countries seem to have a high dependency on remittances. This dependency raised from 2 percent of the total GDP in the mid-1990s to 6.5 percent in 2008. Although the latter increase may partly be explained by the more efficient accounting of remittances in poor countries (da Haas, 2011), Figure 1 also suggests that remittance dependency might be higher in poorer countries in comparison to wealthier ones.

Figure 1

Workers' Remittances and Compensation of Employees - Received (\% of GDP) (1982-2009)

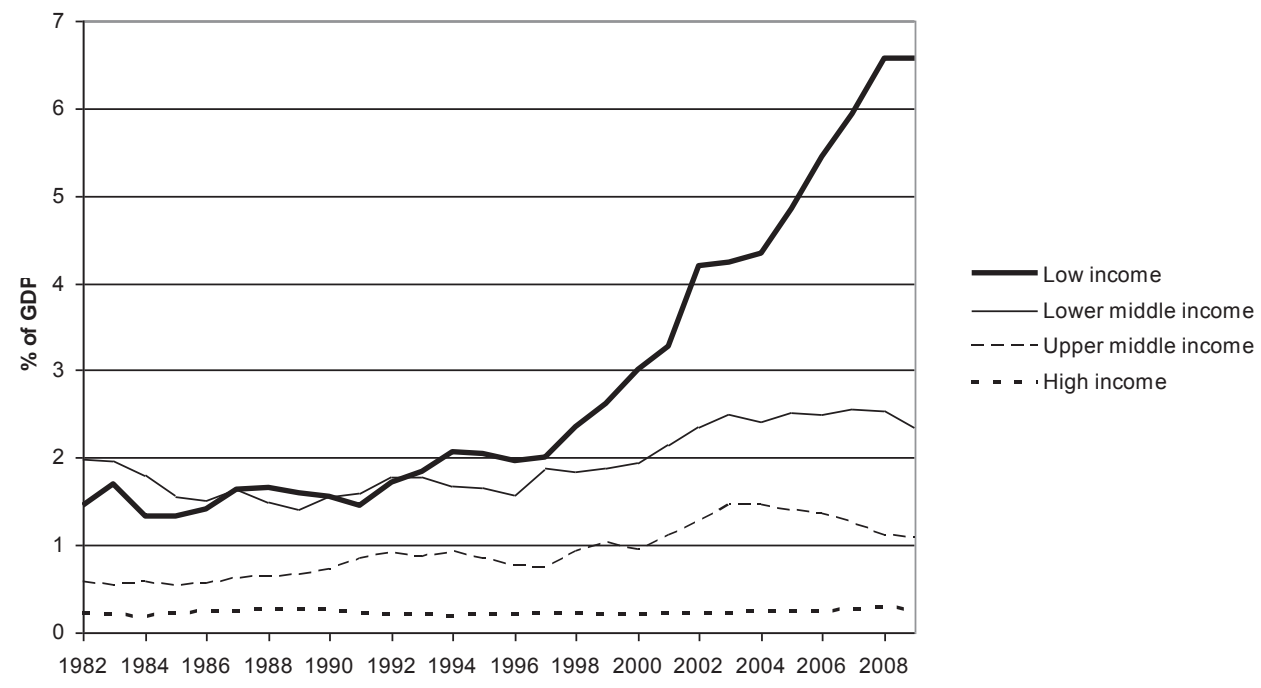

Source: World Development Indicators database, World Bank (2011).

Moreover, we modify the model described by (1) in order to check for the importance of remittances and their significance in comparison with the ODA for the annual GDP growth.

In order to do so, we employ the variables specified above by different groups of countries - the low-income (1), lower middle-income (2), upper middle-income (3) and high-income (4) countries. Similar to the previous case, we employ the available data from the World Bank (2011) for the period of 1970-2009. Our estimations were done using the 2SLS technique. The results of all four estimations are presented in Table 10. 
Table 10

Results of the Model Estimations: Annual GDP Growth, Low-income, Middle-income and High-income Countries (1970-2009)

\begin{tabular}{|l|c|c|c|c|}
\hline \multicolumn{1}{|c|}{ Variables } & $\begin{array}{c}(\mathbf{1}) \\
\text { Low-income }\end{array}$ & $\begin{array}{c}(\mathbf{2}) \\
\text { Lower } \\
\text { middle-income }\end{array}$ & $\begin{array}{c}(\mathbf{3}) \\
\text { Upper } \\
\text { middle-income }\end{array}$ & $\begin{array}{c}(\mathbf{4}) \\
\text { High-income }\end{array}$ \\
\hline Remittances & $0.374^{*}$ & $0.026^{*}$ & -0.591 & -0.042 \\
$(.397)$ & $(.150)$ & $(.894)$ & $(2.665)$ \\
\hline ODA & $-1.373^{*}$ & -0.108 & $-3.078^{*}$ & -0.013 \\
& $(.759)$ & $(.122)$ & $(1.620)$ & $(.062)$ \\
\hline GDP per capita & -0.671 & 0.165 & 1.482 & $0.06^{\star *}$ \\
\hline Savings & $(1.130)$ & $(.238)$ & $(1.752)$ & $(2.763)$ \\
\hline Openness & $5.840^{*}$ & -0.716 & -2.66 & 0.598 \\
& $(2.435)$ & $(774)$ & $(5.803)$ & $(1.610)$ \\
\hline Inflation & 1.750 & -0.033 & $-6.797^{*}$ & -0.058 \\
& $(1.146)$ & $(155)$ & $(4.110)$ & $(1.766)$ \\
\hline Constant & 0.039 & 0.007 & 0.077 & -0.026 \\
& $(.073)$ & $(.011)$ & $(.068)$ & $-111)$ \\
\hline R-squared & 60.006 & 4.156 & -57.088 & -2.191 \\
\hline Adjusted R-squared & $(28.835)$ & $(4.328)$ & $(47.293)$ & $(9.422)$ \\
\hline No of observations & 0.91 & 0.96 & 0.73 & 0.92 \\
\hline (years) & 0.85 & 0.94 & 0.59 & 0.90 \\
\hline
\end{tabular}

Note: * Significant at the $10 \%$ level; ** Significant at the $5 \%$ level; *** Significant at the $1 \%$ level;

Standard errors are shown in parentheses.

Source: Authors' own calculations.

Our results show that remittances have a small but significantly positive effect on economic growth (in our case the logarithm of the growth rate of GDP per capita) in the case of lower-middle income countries and low-income countries. As for the ODA, the coefficients' values are negative for all four groups of countries, being significant only in the case of low-income and upper middle-income countries (see Table 10) .

The negative and significant coefficient of remittances in the case of high-income countries might be explained by the diminishing effect of remittances on wealthier economies (Figure 1). Our results suggest that remittances are at least no less significant than ODA in influencing economic growth in the case of lower-income countries.

9 There are several concerns about this estimation: the most important one is the possibility of nonlinearity. Although our analysis suggests a positive impact of remittances on economic growth, the relationship between these variables might be non-linear. Therefore, all interpretations of our statistical analysis should be taken with care. 


\section{Conclusions}

We conclude that in general remittances might have a higher development potential for developing countries than ODA. This is not only based on the quantitative side (remittances being higher than ODA funds) but foremost on the question of effectiveness and the stability of the flow. Remittances also represent a more stable source of income than ODA in time of economic crises demonstrating on the data from recent global economic recession and financial crisis in South-East Asia at the end of the 1990s.

Our empirical model supports the evidence from migration literature: remittances have a larger net effect on economic growth expressed as the annual growth of GDP per capita in developing countries. Although our empirical models cannot be used for predicting statistical trends due to the low number of observations, it reveals some general trends that are worth taking into account when comparing the effects of remittances and ODA on source countries.

We are far from underestimating the importance of ODA in developing countries and the crucial role of organizations such as the United Nations or the World Bank in disseminating international aid to people in need. However, it is useful to know that there are other possibilities that might be more effective. To that effect more in-depth econometric models based on new data regressions are under construction.

\section{References}

Adams, R. H. (1998), "Remittances, Investment, and Rural Asset Accumulation in Pakistan", Economic Development and Cultural Change, 47, pp. 155-173.

Adams, R. H., Page, J. (2005), "Do International Migration and Remittances Reduce Poverty in Developing Countries?" World Development, 33(10): pp. 1645-1669.

Amin, S. (2006), "The Millennium Development Goals. A Critique from the South". Monthly Review, March 2006.

Arndt, C, Jonnes, S., Tarp, F. (2010), "Aid, Growth, and Development: Have We Come Full Circle?" Journal of Globalization and Development, 1 (2).

Bauer, P. T., Yamey, B. S. (1985), "Foreign Aid: Rewarding Impoverishment?" Commentary, September 1985, pp. 38-40.

Brown, S. S. (2006), "Can Remittances Spur Development? A Critical Survey." International Studies Review, 8 (1): pp. 55-75.

Burnside, C. and Dollar, D. (2000), "Aid, Policies, and Growth." American Economic Review, 90: pp. 847-68.

Cahlíková, Z., Stojanov, R. (2013): "Development-induced Displacement: The Case Study of Slezská Harta Dam in the Czech Republic", Problemy Ekorozwoju, 8 (2): 75-84.

Chambers, R. (2003), Whose Reality Counts? Putting the First Last. Reprint version. London: ITDG Publishing.

Collier, P. (2007), The Bottom Billion. Oxford, United Kingdom: Oxford University Press.

Collier, P., Dollar, D. (2002), "Aid Allocation and Poverty Reduction." European Economic Review, Vol. 45: pp. 1470-500.

Cumby, R., Huizinga. J., Obstfeld, M. (1983), "Two-step Two-stage Least Squares Estimation in Models with Rational Expectations." Journal of Econometrics, Vol. 21, Issue 3, pp. 333-355. 
Dalgaard, C., Hansen, H., Tarp, F. (2004), "On the Empirics of Foreign Aid and Growth." Economic Journal, 114(496): F191-F216, 06.

De Bruyn, T., Wets, J. (2006), "Remittances in the Great Lakes Region." IOM Migration Research Series, No. 25.

De Haas, H. (2011), "The Migration and Development Pendulum: A Critical View of Research and Policy". Paper presented at International Conference "The Migration-Development Nexus Revisited: State of the Art and Ways Ahead," University of Trento, June.

Durand, J. et al. (1996), "International Migration and Development in Mexican Communities." Demography 33(2): pp. 249-264.

Easterly, W. (2009), "How the Millennium Development Goals are Unfair to Africa." World Development, 37(1): pp. 26-35.

Ellis, F. (2003), "A Livelihoods Approach to Migration and Poverty Reduction." Paper Commissioned by the Department for International Development (DFID), Contract No: CNTR 034890.

Giliani, I., Khan, M. F., Iqbal, M. (1981), "Labour Migration from Pakistan to the Middle East and its Impact on the Domestic Economy." Final Report, Research Project on Export of Manpower to the Middle East, World Bank, Washington DC.

Glazar, O., Strielkowski, W. (2010), "Turkey and the European Union: Possible Incidence of the EU Accession on Migration Flows." Prague Economic Papers, (19)3: pp. 218-235

Görlich, D., Trebesch, Ch. (2008), "Seasonal Migration and Networks - Evidence on Moldova's Labour Exodus." Review of World Economics (Weltwirtschaftliches Archiv), 144(1): pp. 107-133.

Gupta, S., Pattillo, C., Wagh, S. (2006), Are Donor Countries Giving More or Less Aid? Review of Development Economics, 10(3): pp. 535-552.

Gyimah-Brempong, K., Racine, J. S., Gyapong, A. (2012), "Aid and Economic Growth: Sensitivity Analysis." Journal of International Development, 24(1): pp. 17-33.

Hausman, J. A. (1978), "Specification Tests in Econometrics." Econometrica, 46(6): pp. 1251-1271.

Horký, O. (2011), "The False Neutrality of the Neoclassical Theory: Feminist, Anthropological, Evolutionary and Ecological Critiques." Politická ekonomie, 59(3): pp. 329-344.

Jamborová, M. (2008), "On the Effectiveness of the Development Assistance," in Stojanov et al. (2008), Development Assistance in the Light of Practice. Selected Linkages and Aspects. Olomouc: Palacký University, pp. 47-82.

Jha, S., Sugiyarto, G., Vargas-Silva, C. (2009), "The Global Crisis and the Impact on Remittances to Developing Asia." Asian Development Bank Economics Working Paper Series No. 185, Asian Development Bank.

Joly, D. (2000), "Some Structural Effects of Migration on Receiving and Sending Countries." International Migration, 38(5): pp. 25-38.

Katseli, L. T., Lucas, R. E. B., Xenogiani, T. (2006), "Effects of Migration on Sending Countries: What Do We Know?" Paris: OECD Development Centre. Working Paper No. 250.

Lancaster, C. (1999), Aid to Africa. So Much to Do, So Little Done. Chicago: A Century Foundation.

Lensink, R., White, H. (2001), "Are There Negative Returns to Aid?" Journal of Development Studies, 37(6): pp. 42-65.

Loots, E. (2006), "Aid and Development in Africa: The Debate, the Challenges and the Way forward." South African Journal of Economics, 74(3): pp. 363-381.

Macrae, J. (2001), Aiding Recovery? The Crisis of Aid in Chronic Political Emergencies. London: Zed Books.

Mohapatra, S., Ratha, D., Silwal, A. (2010), Outlook for Remittance Flows 2011-12. Recovery after the Crisis, but Risks Lie ahead. Migration and Development Brief 13, Washington D.C.: Migration and Remittances Unit, World Bank. Available at www.worldbank.org.

Massey, D. S. et al. (1993), "Theories of International Migration: A Review and Appraisal". Population and Development Review, 19(3): pp. 431-466. 
Moyo, D. (2009), Dead Aid. Why Aid Is not Working and How There Is Another Way for Africa. Penguin Books, London, United Kingdom.

OECD (2011), "Statistics on Resource Flows to Developing Countries." [online]. Paris: Organisation for Economic Co-operation and Development. [Accessed 2012-03-24]. Available from www.oecd. org

OECD (2012), "Development: Aid to Developing Countries Falls because of Global Recession." [online]. Paris: Organisation for Economic Co-operation and Development. [Accessed 2012-08-31]. Available from http://www.oecd.org

Ovaska, T. (2003), "The Failure of Development Aid." Cato Journal, 23 (2): pp. 175-188.

Ratha, D., Mohapatra, S., Silwal, A. (2010), "Migration and Remittances Factbook 2011." Development Prospects Group, World Bank, Washington D.C., USA.

Sachs, J. (2005), The End of Poverty. How We Can Make It Happen In Our Life. London: Penguin Books.

Schoorl, J. et al. (2000), Push and Pull Factors of International Migration: A Comparative Report. Luxembourg: Office for Official Publications of the European Communities.

Skeldon, R. (2002), "Migration and poverty." Asia-Pacific Population Journal, 17(4): pp. 67-82.

Skeldon, R. (2005), "The Millennium Development Goals and Migration." Workshop on Migration and Development: Mainstreaming Migration into Development Policy Agendas, Geneva, 2.-3. February 2005.

Stojanov, R., Duží, B. (2013), “Migrace jako adaptace na změnu klimatu”. Mezinárodní vztahy, 48(3): pp. 9-31.

Stojanov, R., Jamborová, M. (2008), "Millennium Development Goals - News of Idle Hope in Development Aid and Inadequate Indicators," in Stojanov et al. (2008): Development Assistance in the Light of Practice. Selected Linkages and Aspects. Olomouc: Palacký University, pp. 97-108.

Stojanov, R., Kavanová, K. (2009): "Environmental Migrants: Introductory Reflections on the Concept." [El concepto de migrantes medioambientales (comentarios introductorios)] Estudios Migratorios Latinoamericanos, 23(68): pp. 39-54

Stojanov, R., Novosák, J. (2008), "Migrace místo pomoci? Remitence a cirkulace mozků jako nástroje rozvoje." Mezinárodní vztahy, 43(1): pp. 38-77.

Stojanov, R., Strielkowski, W., Drbohlav, D. (2011), "Labour Migration and Remittances: Current Trends in Times of Economic Recession." Geografie, 116(4): pp. 375-400.

Taylor, J. E. (1992), "Remittances and Inequality Reconsidered: Direct, Indirect, and Intertemporal Effects." Journal of Policy Modelling, 14(2): pp. 187-208.

Thérien, J.-P., Lloyd, C. (2000), "Development Assistance on the Brink". Third World Quarterly, 21 (1): pp. 21-38.

Vargas-Silva, C. (2011), "Remittances and Development: Recent Evidence in the Times of Financial Turbulence". Paper presented at International Conference "The Migration-Development Nexus Revisited: State of the Art and Ways Ahead", University of Trento, June.

World Bank (1998), "Assessing Aid: What Works, What Doesn't, and Why." The World Bank Policy Research Report, Oxford: Oxford University Press.

World Bank (2011): "Remittance Market Outlook." [online]. Available at http://go.worldbank.org/ NPD63OTRR0.

World Bank (2012), "World DataBank.” [online] Available at: http://databank.worldbank.org/data/home. aspx.

Wucker, M. (2004), "Remittances: The Perpetual Migration Machine." World Policy Journal, 21(2): pp. 37-46. 